Primljeno: 20. 9. 2020.

Prihvaćeno za štampu: 23. 11. 2020.

\author{
Dr. sc. Hajrudin Hodžić, van. prof. \\ Univerzitet u Bihaću \\ Islamski pedagoški fakultet \\ E-mail: bajrudinhodzi@gmail.com
}

\title{
SEMANTIČKE RAZLIKE IZMEĐU SINONIMA KAO PRIMJER BOGATSTVA ARAPSKOG JEZIKA
}

\section{Sažetak}

Semantičke raحlike između sinonima (ar. al-furūq al-lugawiyya - الفروق اللغوية) su naučna disciplina $u$ arapskom jeziku koja istražuje razlike između pojedinih riječi koje, na prvi pogled, imaju identična značenja.

Značaj izučavanja ove teme se ogleda u što preciznijem tumačenju i shvatanju sakralnih tekstova (Kur'ana i riječi Mubammeda, s.a.v.s.,), zatim čuvanju bogate arapske leksike, kao i trganju od zaborava izraza koji imaju preciznija značenja.

U prvom periodu stasanja arapske leksikografije, autori koji su pisali djela iz ove naučne discipline su dali veliki doprinos njenom bogaćenju, a jedno od najpoznatijith djela je Al-Furūq al-lugamiyya (الفروق اللغوية) 'Abū Hiläla al-'Askariyya (395/1005).

Ključne riječi: arapski jezik, semantičke razlike ižmeđu sinonima (al-furüq allugawiyyadالفروق اللغوية bogatstvo arapskog jerika, sinonimija, komentar Kur'ana

\section{Uvod}

Činjenica da je arapski jezik odabran da bude jezikom zadnje Božije objave dovoljno govori o njegovom značaju i bogatstvu njegove leksike koja je dovoljno sadržajna da prenese sve eksplicitne i implicitne božanske poruke čovječanstvu. Podatak kojeg navodi Subhi al-Salih (Ṣubḥi al-Ṣāliḥ) da su savremene studije pokazale da arapski jezik broji 
oko dvanaest miliona riječi, od čega je u upotrebi samo oko osamdeset hiljada - najbolji je dokaz i pokazatelj o kakvom, skoro neuporedivom, leksičkom bogatstvu je riječ (Al-Ṣāliḥ 2009: 168).

Arapski jezik se odlikuje izuzetno velikim brojem sinonima. Stručnjaci iz oblasti arapske jezikoslovne znanosti ističu da $\mathrm{u}$ arapskom jeziku za lava ima oko 500 naziva, za devu oko 250 , za med više od 80 , za sablju najmanje 1000, za nesreću oko 400, itd. (Muftić 1998: 679). Također, neki pridjevi u arapskom jeziku imaju velik broj sinonima, poput: dug, kratak, darežljiv, škrt, hrabar, plašljiv i dr.

Zaljubljenost Arapa u maternji jezik, preciznost $u$ njihovom izražavanju, kao i bogatstvo arapske leksike u cijelosti ih je motivisala da mu posvete veliku pažnju iz koje je proistekao veliki broj sinonima.

Značaj izučavanja ove teme se ogleda, prvenstveno, u činjenici da će nam ona pomoći u ispravnom i preciznom shvatanju kur'anskog teksta i izreka Muhammeda, s.a.v.s., jer se iz njih crpe propisi koji predstavljaju smjernice cjelokupnom čovječanstvu do Sudnjega dana, pa je njihovo precizno poimanje veoma važno. Poruke kur'anskohadiskih tekstova su svevremene. Njihovi tekstovi su izrečeni prije četrnaest stoljeća i eventualno pogrešno shvatanje njihovih poruka ili neudubljivanje u njihova precizna i decidna značanja mogu uveliko otežati njihovu primjenu u svakodnevnom životu. Stoga je pronicanje u najsitnije i najtananije elemente njihovih značenja od suštinske važnosti za shvatanje Božije objave i postupanja po njoj.

Značaj ove teme se ogleda i u činjenici da predstavlja historijsko svjedočenje o bitnoj fazi razvoja arapske leksičke misli, s obzirom na to da su Arapi pridavali veliku pažnju svom jeziku i čuvali ga od zaborava, što je rezultiralo spremnošću arapskog jezika da odgovori na izazove koji se postavljaju ispred njega $u$ kontekstu iznalaženja leksičkih rješenja za sve pojave vezane za savremeni tehnološki napredak.

Ukoliko bismo pokušali definisati ovu jezičku disciplinu mogli bismo reći da su al-furūq al-lugiawiyya, kako je arapski filolozi nazivaju, ustvari, neznatne razlike između riječi čija su značenja toliko slična, a njihova upotreba različita, da ih može razlučiti samo vrstan lingvista (Al-Dūrī 2005: 15). 
Jedan dio arapskih lingvista je posvetio posebnu pažnju semantičkim razlikama između sinonima i napisao veoma značajna djela koja će biti važan izvor za kvalitetnije shvatanje, prvenstveno kur'anske poruke čovječanstvu, a zatim jezika u cijelosti.

Ebu-Osman Amr ibn Bahr al-Džahiz ('Abū 'Uțmān 'Amr 'ibn Baḥr alĞāhiz, 255/869) je među prvima prepoznao značaj ove naučne discipline i ukazao na bitnost njenog uvažavanja, kada je u svom djelu Al-Bayān wa al-tabyīn (البيان والتبيين) konstatovao da se ,često koriste izrazi, iako postoje drugi preči za korištenje“. Naprimjer, Uzvišeni Allah izraz al-ğūu الجوع -,glad“ u Kur'anu spominje samo u kontekstu kazne, siromaštva ili evidentne nemoći, dok u stanju zdravlja i sposobnosti niko ne spominje izraz al-sagab السغب, -glad“, nego koriste izraz al-ğū' - ,glad“،. Isti je slučaj sa izrazom al-maṭar المطب „kiša“; on se u Kur'anu spominje isključivo u kontekstu osvete i kazne, a običan narod, pa i značajan broj obrazovanih, ne prave razliku između izraza al-mațar المطر i al-gayt الغيث -,kiša“ (iako se zadnji u Kur’anu koristi za blagorodnu kišu, op. aut.)“(Al-Ğāḥiz 1998: 1/20).

Ova Džahizova opaska bila je inspiracija mnogima da se ozbiljnije pozabave ovim fenomenom i jezičkom disciplinom poznatijom $\mathrm{u}$ arapskom jeziku kao al-furūq al-lugiawiyya - semantičke razlike između sinonima $u$ arapskom jeziku.

Isto tako, ne treba gubiti iz vida činjenicu da riječi ne ostaju uvijek iste, ni po svojoj formi, ni značenju, tj. one su izložene raznim manjim ili većim fonetskim, morfološkim ili semantičkim promjenama. Neke od njih se gube iz stalne upotrebe, druge se mijenjaju, dok neke druge postaju nove tvorevine. Naprimjer, riječ dabbāba - دبابة je nekada značila opsadnu, primitivnu spravu, zaštitni pokrovac, ispod kojeg su se napadači sklanjali od opsjednutih, prilazeći im tako pod zidine grada. Danas se ta riječ upotrebljava za borna kola, tenk (Muftić 1998: 670).

\section{Al-Furūq al-luǵawiyya i sinonimija}

Postoje velike razlike u definisanju sinonimije među arapskim lingvistima, s obzirom na to da neki od njih uslovljavaju potpunu podudarnost značenja, dok drugi dozvoljavaju određene razlike i odstupanja u značenju između njih, pod uslovom da učestvuju u osnovnom značenju (Al-Šāyi‘ 1993: 36). To, prema njima, znači, da 
postojanje određenih, djelimičnih razlika u značenju nije razlog da se za njih koristi termin sinonim. ${ }^{1}$

Ugledni arapski lingvista Ibrahim Anis ('Ibrāhīm 'An̄̄s) navodi četiri uvjeta da se dvije riječi smatraju sinonimima:

a) potpuno međusobno slaganje njihovih značenja,

b) jedinstvo jezičke sredine u kojoj se upotrebljavaju,

c) istodobnost njihove upotrebe,

d) da sinonimi ne budu rezultat glasovnog razvoja iz istog korjena ('Anīs 1992: 178).

Ispunjenost ova četiri uvjeta je u praktičnom smislu teška, pa se zbog toga konstatovalo da je apsolutna podudarnost značenja sinonima veoma rijetka. Pojedinci su pokušavali dokazati postojanje apsolutne sinonimije, tj. da se zamjenom jednog sinonima drugim postigne identično značenje, ali su se praktično susreli s primjerima koji su njihovu teoriju dovodili u pitanje (Muftić 1998: 675).

Zbog toga su pojedini, veoma ugledni arapski lingvisti, negirali praktično i stvarno postojanje sinonima $u$ arapskom jeziku, među kojima su Al-Táa'ālibī, Al-Fārisī, Al-Bayḍāwīe Ibn al-’A'rābiyy i drugi (Muftić 1998: 676). Svoj stav potkrepljuju značajnim argumentima. Oni smatraju da bi bilo idealno da na svaki pojam ukazuje samo jedan izraz, a ne više njih, zbog čega nema potrebe za postojanjem sinonimije ili polisemije, jer ako imamo više izraza, to podrazumijeva da imamo i više pojmova. Oni smatraju da bi bilo nepotrebno i nepraktično da se za svaki pojam koristi više izraza, jer bi to značilo proširivanje jezičke leksike, što je nepotrebno jer priroda života teži ka pojednostavljivanju i skraćivanju stvari.

Također, oni smatraju da ono što se smatra sinonimom, ustvari nije sinonim, jer su Arapi pravili razliku između riječi, a naše nepoznavanje tih razlika ne znači da ona ne postoji, kao što je slučaj s riječima sayf

\footnotetext{
Pojedini autori te dvije kategorije sinonima nazivaju istoznačnicama i bliskoznačnicama (vidi: Mihić, Tina, ,Sinonimi i razlike u hrvatskim prevodima na primjeru Lk 22,54-62“, Lahor, 2012. str. 138-174).
} 
(sablja“i i husām -,oštra sablja“, gdje prva ukazuje na sablju kao pojam, dok drugi predstavlja pridjev za isti pojam, itd.

$\mathrm{S}$ druge strane, pojedini arapski lingvisti dovode $\mathrm{u}$ pitanje postojanje furūqa kao naučne discipline. Oni smatraju da sve navedeno potpada pod sinonimiju (tj. djelimičnu sinonimiju ili bliskoznačenice) koja se smatra jednom od glavnih karakteristika i obilježja arapskog jezika, te da se time osobi koja govori arapskim jezikom ostavlja velika mogućnost izbora sinonima u svakodnevnom govoru.

Značajnu ulogu u bogaćenju arapske sinonimije imala je i geografska rasprostranjenost Arapskog svijeta. Ako bismo uzeli, naprimjer, pojam „pšenica“ za koji se u arapskom jeziku koriste tri različita termina: qamh - قمح , حنطة - inta burr - vidjeli bismo da svaki od njih ima svoje geografsko porijeklo; pa tako qamh - قمح dolazi iz šamskog dijalekta, hinta - حنطة iračkog, a burr - بر hidžazijskog dijalekta (AlŠàyi‘ 1993: 64).

Ako bismo cjelokupno lingvističko područje arapskog jezika smatrali jedinstvenim, onda bismo prethodno navedene riječi smatrali sinonimima, ali ako bismo uzeli u obzir prostornu (dijalektnu) ograničenost upotrebe takvih riječi, i pored identičnosti njihovih značenja, onda ih ne bismo moglo ubrojati u stvarne sinonime (Muftić 1998: 676). S obzirom na to da područje arapskog jezika (u lingvističkom smislu) smatramo jedinstvenim, onda te grupe riječi možemo smatrati sinonimima.

Analizirajući djela arapskih filologa nailazi se na veoma opsežne rasprave na ovu temu. Siže tih rasprava bi mogao biti da postoje razlike između pojedinih sinonima, ali da je nemoguće ustvrditi razliku između pojedinih sinonima, što nam ukazuje na postojanje apsolutne (tzv. istoznačnica) i djelimične sinonimije (bliskoznačnica), tako da bi se jezička disciplina al-furūq al-luġawiyya mogla podvesti pod djelimičnu sinonimiju.

Koliko su rasprave o temi sinonima kompleksne, govori i podatak da značajan broj autora među kojima je i Branka Tafra smatrajući da se ova tema ne može iscrpiti i o njoj se znanstvenici nikada neće složiti (Tafra 2018: 215). 


\section{Uzroci pisanja djela iz oblasti al-furūq al-lugawiyya}

Djela iz ove jezičke discipline predstavljaju značajan iskorak u prvim stoljećima nastajanja arapske leksikografije i zaslužuju da se prezentiraju široj javnosti zbog značajne uloge koju imaju u čuvanju i bilježenju velikog arapskog leksičkog blaga.

Uzroci koji su motivisali autore da pišu djela iz ove oblasti mogu se sažeti u sljedećem:

a) očuvanje arapskog jezika, kao jezika Objave, nedvojbeno predstavlja glavni motiv autorima koji su pisali o ovoj tematici, strahujući da bi se vremenom, posebno susretom Arapa s drugim narodima i civilizacijama, ovo ogromno bogatstvo moglo izgubiti;

b) oživljavanje i nanovo aktueliziranje leksike koja se vremenom počela zanemarivati i zapostavljati, jer se stanovništvo počelo oslanjati na manje preciznu leksiku, koja je samo djelimično zadovoljavala traženo značenje, zanemarujući preciznije i adekvatnije sinonime, kao što je to slučaj s imenima ljudskih i životinjskih organa koji su po svojoj ulozi možda slični, ali su po nazivu i formi različiti, kako to primjećuje Ibrahim Anis navodeći da je to iz razloga što „narod naginje da se u svom svakodnevnom životu zadovolji manje preciznim i konkretnijim izrazima koji ispunjavaju cilj njihovog govora i komuniciranja“" ('Anīs 1992: 178-179). Al-Salih smatra ,da su ove razlike, čini se, vremenom zaboravljene i jezik kojem pripadaju ima pravo da ih smatra svojom svojinom i dokazom svoga bogatstva i brojnosti svojih sinonima“" (Al-Șāliḥ 2009: 300);

c) lingvisti su imali za cilj da time dodatno educiraju narod i ukažu običnom puku na prenesena, figurativna značenja kojeg su uobičajili koristiti pisci i pjesnici, kako bi se istaklo osnovno i precizno značenje pojedinih sinonima, a pažnja skrenula na to šta je osnovno, a šta preneseno značenje i način njegovog korištenja ${ }^{2}$ (Kulayb Musa 2006: 13-15).

Vođeni ovim uzrocima, značajan broj arapskih lingvista je posvetio zasebna djela ovoj tematici i time joj pridao posebnu pažnju,

\footnotetext{
${ }^{2}$ Navedenim uzrocima bi se mogli dodati i drugi uzroci, među kojima je stav autora da ne postoji apsolutna sinonimija i dr.
} 
pokušavajući time otrgnuti od zaborava značajan dio arhaizama ovog bogatog jezika.

\section{Autori koji su pisali o ovoj tematici}

Veliko jezičko naslijeđe, koje je proisteklo iz Kur'ana, izreka Muhammeda, s.a.v.s., kao i stare arapske poezije i proze, predstavljalo je izvor za brojne autore koji su u prvim stoljećima poslije dolaska islama sastavljali specijalizirane poslanice o pojedinim oblastima, poput imena životinja i slično.

Prvi koji su pisali samostalna djela o ovoj jezičkoj disciplini su autori koji su zagovarali apsolutnu sinonimiju, a prvi među njima je Al-Asmai (Al-'Așma'iyy, 216/831) koji je napisao samostalno djelo koje nosi naziv Mã ihtalafat 'alfāzuhū wa ittafaqat ma 'ānīh (ألفاظه واتفت ما اختلفت معانيه $)^{3}$. Ostali autori koji su uviđali razliku između sinonima krenuli su u pravcu pisanja zasebnih djela o ovoj tematici, jer su te razlike, ma koliko one bile sitne, ipak postojale i bile uočljive, nakon čega je značajan broj njih, prvenstveno onih koji su se protivili teoriji apsolutne sinonimije, napisao djela kojima su praktično opovrgavali navedenu teoriju. Među njima su se isticali Ibn al-Sikkīt (244/858) djelom 'Iṣlăh al-manțiq (إصلاح المنطق), zatim Quțrub djelom Kitāb al-farq (كتاب الفرق)), zatim 'Abū Manșūr al-Ta`ālibiyy (429/1038) djelom Fiqh al-luğa wa 'asrār al- 'arabiyya (فقه اللغة وأسرار العربية), kao i mnogi drugi.

S obzirom na brojnost djela koja su obrađivala ovu tematiku, mi ćemo u ovom radu ukratko prezentirati tri reprezentativna djela:

\section{Djelo „Al-Furūq al-luǵawiyya“ od 'Abū Hilāla al-'Askariyya}

Među najpoznatijim djelima, ako ne i najpoznatije djelo koje je obilježilo ovu disciplinu jeste djelo 'Abū Hilāla al-'Askariyya pod nazivom Al-Furūq al-luġawiyya, ujedno i najreprezentativnije djelo iz ove discipline.

\footnotetext{
${ }^{3}$ Iz samog naslova se nazire da autor ne koristi termin tarāduf-sinonimija, nego ga autor pojašnjava riječima, što ukazuje da se on kao termin do tada još uvijek nije ustabilio. Prvi koji je ovaj termin koristio bio je 'Abū al-Hasan 'Ali bin 'Īsā al-Rumān̄̄ (384/994), autor djela Al-'Alfāz al-mutarādifa, čime je prvi ustanovio termin tarāduf za sinonimiju.
} 
Autor u samom uvodu ukazuje na motive pisanja djela, a koji se ogledaju u nedovoljnom broju djela iz ove discipline, zatim sve učestalijem pogrešnom korištenju pojedinih izraza, ali i zbog sličnosti njihovih značenja.

Knjigu je podijelio u trideset naslova, a svaki od njih ima zajednički imenitelj. Posebnu pažnju pridao je osnovnom etimološkom značenju.

Njegov lični stav o apsolutnom negiranju sinonimije dovodila ga je $\mathrm{u}$ situaciju da nije mogao posegnuti za pojašnjenjem pojedinih riječi drugim izrazima iz Kur'ana ili nekog drugog izvora, kao što su arapska poezija ili proza.

Opća je ocjena da se autor nije bavio raritetima, niti mu je to bio cilj pisanja knjige, nego se želio posvetiti izrazima zastupljenim u Časnom Kur'anu, terminologiji islamskih pravnika i apologetika, kao i leksici iz uobičajenih svakodnevnih dijaloga.

Pojedini autori dovode u pitanje autorstvo ovoga djela 'Abū Hilālu al'Askariyyu, jer je samo nekoliko biografa potvrdilo njegovo autorstvo, ali je u naučnim krugovima ovo djelo opće prihvaćeno kao djelo 'Abū Hilāla al-'Askariyya i kao jedno od temeljnih djela iz ove oblasti. Knjiga je doživjela mnogo izdanja, a jedno od njih je u izdanju izdavačke kuće Dāl al-‘ilm wa al-țaqāfa iz Kaira u 320 strana.

\section{Fiqh al-luġa wa 'asrār al-‘arabiyya od 'Abū Manșūra al- Ta‘ālibiyya (429/1038)}

Knjiga počinje predgovorom o značaju arapskog jezika i motiva kojim se autor rukovodio prilikom pisanja djela. Autor navodi da ga horasanski emir 'Ubaydullāh b. Aḥmad al-Mīkālī, u čijem okruženju je živio i djelovao, motivisao da napiše jedno ovakvo djelo.

Autor je na sebi svojstven i jednostavan način zaronio u more arapskog jezika i kroz brojne primjere i poređenja ponudio čitatelju bisere arapskog jezika. Jezičku materiju je grupisao i logičkim slijedom prezentirao u radu. Tako, naprimjer, u prvom dijelu knjige, Poglavlje o prvim $i$ zadnjim stvarima, na jednostavan način prezentira nazive početka i završetka svih stvari, uz navođenje argumenata za svoje tvrdnje iz Kur'ana, izreka Muhammeda, s.a.v.s., i arapske poezije. 
Autor se, također, rukovodio logikom da prilikom izlaganja materije kreće od općenitijeg ka specifičnijem, pa tako nakon poglavlja broja dvadeset o glasovima, nastavlja s naslovima koji se odnose na vrste glasova s različitih aspekata.

Knjiga se sastoji, kako to i sam naslov nagovještava, iz dva dijela:

a) Prvi dio se sastoji od trideset naslova i na desetine podnaslova. Govori o sinonimima i razlikama među njima (fiqh al-luga);

b) Drugi dio sadrži devedeset i devet kraćih naslova. Ovaj dio obuhvata različite stilove izražavanja u arapskom jeziku ('asrār al- 'arabiyya).

S naučnog aspekta knjiga 'Abū Manșūra al-Ta'ālibiyya predstavlja riznicu i važan izvor za brojne studije i analize semantičkih razlika između sinonima.

Ovo djelo je doživjelo brojna izdanja, a jedno od njih je u izdanju izdavačke kuće Al-Maktaba al-'așriyya iz Bejruta u 611 strana.

\section{Djelo „Furūq al-lugiāt fî al-tamyīz bayna mafād al-kalimāt“ od Nūra al-dīn bin Ni‘matullāh al-Husayniya (1158/1745)}

Jezička materija u djelu je, kako tvrdi autor, posložena po alfabetu. U većini slučajeva je uspoređivao dva, a ponekad i više izraza, a zatim pojašnjavao razlike između njihovih značenja.

Jedna od značajnih odlika ovoga djela jeste mnoštvo citata i argumenata iz Kur'ana, hadiskih zbirki, stare arapske poezije i proze, kao i izreka naučnih autoriteta koje je koristio kao podršku svojim navodima.

Iako je autor djela živio prije manje od 300 godina, zanimljivo je da u ovome djelu tvrdi, da ga i pored bitnosti same teme, niko nije pretekao u pisanju djela na ovu tematiku, što je, zbog svega navedenog netačno. Djelo je štampano u Teheranu na 697 strana.

Bitno je istaći i činjenicu da pojedina djela ne spadaju u ovu naučnu disciplinu, iako se njihovi naslovi mogu dovesti u vezi s njima, poput djela Al-Furūq (الفروق) od Al-Qarāfiya, Al-Ta'rīfāt (التعريفات) od AlĞurğāniya, Al-Mușțalaḥāt (المعردات) od Al-Tahānawiya ili AlMufradāt (الففردات) od Ibn-Bayțāra, jer ona obrađuju stručnu terminologiju drugih naučnih specifičnih oblasti, a ne leksičku građu. 


\section{Značaj poznavanja semantičkih razlika u komentaru kur’anske leksike}

Tragajući za ispravnim i preciznim shvatanjem kur'anskih poruka tokom prethodnih četrnaest stoljeća od objave Kur'ana, arapski lingvisti su se dali u potragu za skrivenim razlikama u značenju između pojedinih kur'anskih leksema, posebno imajući u vidu činjenicu da Kur'an na pojedinim mjestima koristi jedan sinonim, a na ostalim mjestima drugi. Komentatori Kur'ana su tragali za mudrošću korištenja pojedinih izraza i dolazili do zanimljivih i veoma korisnih zaključaka.

Preciznost kur'anskog izraza, kako to navodu Al-Duri (Al-Dūrī), ima ključnu ulogu u nadnaravnosti kur'anskog izraza, a semantičke razlike između sinonima su najbolji temelj i pokazatelj te preciznosti.

Spomenuta preciznost se, prema Al-Duriju, manifestuje kroz:

a) preciznost osnovnog značenja kur'anskog izraza,

b) preciznost u opisu,

c) harmoniju kur'anskog izraza s cjelokupnim značenjem Kur'ana, a kao primjer navodi dva sinonima za ljude u Kur'anu: al-bašar البشر

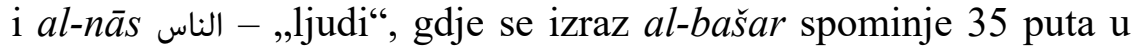
kontekstu isticanja materijalne komponente čovjeka koji je ovisan o hrani i živi običnim ovosvjetskim životom, posebno u kontekstu materijalne dimenzije Božijih poslanika koje nevjernici u laž utjeruju, dok se izraz al-nās koristi u kontekstu psihološke i duhovne dimenzije čovjeka,

d) preciznost u odabiru izraza, kao što je to slučaj s izrazom al-bahs koji ima značenje ,jeftin, mizeran, nepravedan“, tako da nijedan drugi izraz, koji u sebi involvira približna značenja, poput riječi nāqiṣ ناقص ili tafiff ne mogu odraziti sliku koja se njime želi postići,

e) preciznost u određivanju značenja, koje se dobija sastajanjem svih prethodno navedenih oblika, pa tako, naprimjer, glagol ittāqaltum

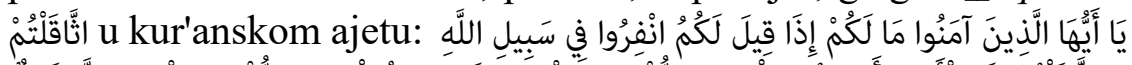
"O vjernici, zašto ste neki oklijevali kada vam je bilo rečeno: 'Krenite u borbu na Allahovu putu!' kao da ste za zemlju prikovani? Zar vam je draži život na ovom svijetu od onoga svijeta? A uživanje 
na ovom svijetu, prema onom na onom svijetu, nije ništa“" (Kur'an 9: 38), koji kada bi se zamijenio s nekim drugim izrazom ne bi mogao ukazati u punom smislu na "prikovanost za zemlju" ili „teškoću” koja se osjeti kroz spajanje tešdida, slova ța' i qāf u jednoj riječi (Al-Dūrī 2005: 21-24).

Zanimljiv primjer jeste korištenje imenice zawğ - „وج „supruga“ i

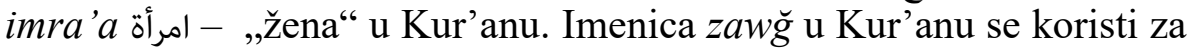
bračnog druga ili općenito para (za živa i neživa bića), te se u kontekstu bračnog druga koristi bez karakterističnog okruglog slova t (ة) za oba roda, tj. za supruga i suprugu. Kada je u pitanju supruga, Kur'an za nju nekada koristi jedan, a nekada drugi sinonim. Preciznom analizom ajeta u kojima se ovi sinonimi spominju dolazi se do zaključka da se prvi

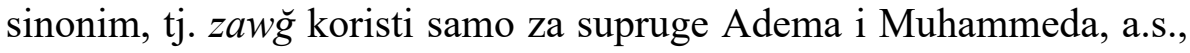
dok se za supruge Nuha, Luta, faraona i Aziza koristi imenica imra'a - امرأة - žena“. Pojedini autori (Al-Dūrī 2005: 97-98) smatraju da je to zbog činjenice da je brak legalna veza koja ukazuje na snagu povezanosti među supružnicima, a manifestuje se kroz vjersku pripadnost, pa kada su supružnici iste vjere, onda se koristi sinonim zawğ - „supruga“, a kada nije koristi se sinonim imra'a - ,žena“. Izuzetak je supruga Zekerijjaha, a.s., za koju je na jednom mjestu korišten jedan, a na drugom, drugi sinonim. Pažljivom analizom dolazi se do zaključka da je u kontekstu govora o nemogućnosti da ostane trudna korišten sinonim imra'a - ,žena“, dok je nakon trudnoće korištena imenica $z a w \breve{g}$ - „supruga“.

Također, Kur'an na brojnim mjestima koristi sintagmu al-'amr bi alma 'rūf wa an-nahy 'an al-munkar - الأمر بالمعروف والنهي عن المنكر, ukazujući time na potrebu naređivanja dobra i odvraćanja od zla. Međutim, zanimljivo da Kur'an u ovoj sintagmi umjesto termina ma 'rūff معروف nije koristio, naprimjer, termin ḩayr - خير ili birr - بر فير kao što nije umjesto termina munkar منكر koristio termin šarr شجور ili fuğ فر tj. nije koristio njihove djelimične sinonime, iako ih je kao termine koristio na drugim mjestima i drugim kontekstima. Razlog je što termini ma 'rüf (particip pasivni od korijena 'arafa - عرف, tj. poznato i prepoznato kao dobro) i munkar (particip pasivni od korijena nakara - نكر, tj. poznato i prepoznato kao zlo) ukazuju na ono dobro ili zlo koje je općeprihvaćeno od strane svih normalnih ljudi, bez obzira na njihov svjetonazor ili pripadnost nekoj ideologiji ili pokretu. 
Iz toga proizilazi da se naređivanje ,dobra“ treba odnositi samo na ono dobro koje je općeprihvaćeno od strane ljudi zdrave i normalne prirode. Isti je slučaj sa ,zlom“ koje se ne odnosi na ono zlo koje neka skupina ili ideološka frakcija tako okarakteriše i pokušava drugima to shvatanje nametnuti, iz čega proizilaze različite nesuglasice i sukobljavanja.

Kur'an za činjenje dobra koristi sintagmu wa 'amilū al-ṣālihāt - وعملوا فعلوا - Zanimljivo je da ne koristi, naprimjer, glagol fa'alü الصالحات umjesto 'amilū - عملوات ili neki drugi glagol. Glagol 'amilū označava radnju koja duže traje, kao da nam time Kur'an ukazuje da vjernici konstantno čine dobra djela, dok glagol fa' $a l u ̄$ označava radnju koja se desi i završi u kratkom vremenskom periodu. Mnoštvo je primjera u Kur'anu koji to potvrđuju, a jedan od njih je ajet u kojem Uzvišeni Allah govori o kažnjavanju ,vlasnika slonova“, kada kaže: أَلَمْ تَرَ كَفَْ فَعَلَ رَبُّكَ Zar nisi čuo šta je sa vlasnicima slona Gospodar tvoj uradio!“", tj. radnja kažnjavanja nije trajala dugo. Također, zanimljivo je da je u istoj sintagmi korištena imenica al-șâliḥât - الصالحات, a ne alhasanāt - الحسنات, jer se imenica al-ṣālihât odnosi na ona djela koja koriste općoj društvenoj zajednici, a ne samo na djela koja koriste isključivo osobi koja ih čini.

Također, Kur'an za godinu koristi dva sinonima: sana - عنة i 'ām - عنة Ako analiziramo njihovo korištenje vidjet ćemo da se imenica sana koristi u kontekstu teških i nerodnih godina, a da se imenica 'àm koristi za rodnu i plodnu godinu. Kao argument uzimaju se dva kur'anska ajeta:

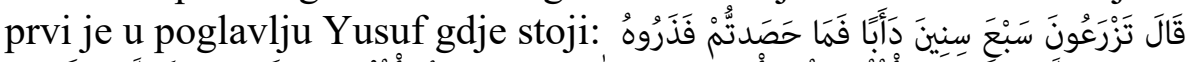

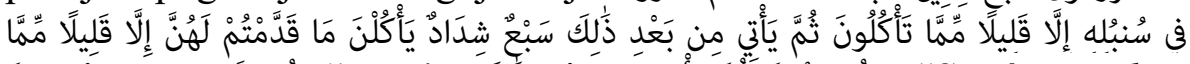

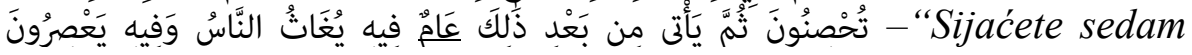
godina uzastopno" - reče - "pa ono što požanjete u klasu ostavite, osim ono malo što ćete jesti, jer će poslije toga doći sedam teških koje će pojesti ono što ste za njih pripremili, ostaće jedino ono malo što ćete za sjetvu sačuvati. Zatim će, poslije toga, doći godina u kojoj će ljudima kiše u obilju biti i u kojoj će cijediti" (Kur'an 12: 47-49), a drugi je u

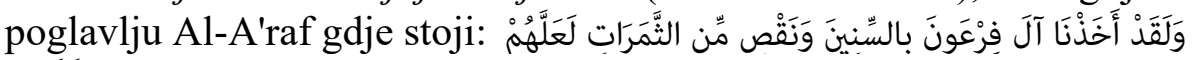

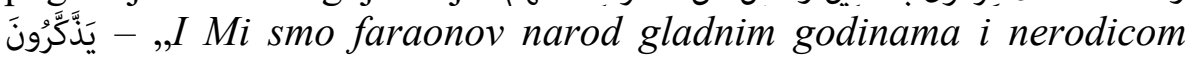
kaznili, da bi se opametili “ (Kur'an 7: 131).

Ovakvih primjera u Kur'anu je mnogo i teško ih je pobrojati. 
Ovaj dio rada mogli bismo zaključiti citatom dr. Fadila al-Samurra'ija (Fāọil al-Sāmurrā̄î) koji, ukazujući na preciznost kur'anskog izraza, kaže sljedeće: „Kur'anski stil je umjetnički ciljani stil. Svaki izraz u njemu, pa čak i svako slovo je umjetnički i ciljano postavljeno, i to nije slučaj samo sa jednim ajetom ili surom, nego je to slučaj sa cjelokupnim Kur'anom. Na to ukazuje statistika koja je potvrđena savremenim istraživanjima koja su jasno ukazala da se u Kur'anu vodila pažnja o svakom slovu, tako da se njemu ne može dodati, niti oduzeti ijedno slovo“ (Al-Dūrī 2005: 21).

\section{Praktični primjeri semantičkih razlika između sinonima u arapskom jeziku}

Najbitniji i vjerovatno čitatelju najzanimljiviji dio rada jesu upravo praktični primjeri razlika između sinonima u leksici arapskog jezika. Mnoštvo je primjera koje autori djela iz ove discipline navode, neki od njih i po nekoliko hiljada primjera, međutim u ovom radu zbog ograničenosti prostora ćemo navesti njih nekoliko.

\section{Sinonimi قسم $i$ حلف}

Riječ se koristi isključivo kada postoji određeni stepen sumnje u ispunjenje onoga zbog čega se zaklinje, dok se riječ قسم koristi za sigurne i jasne situacije, kada se očekuje ispunjenje zakletve. Zbog toga se حلف u Kur'anu koristi u kontekstu lažnog zaklinjanja dvoličnjaka ili pretjeranog zaklinjanja. Međutim, kada se Uzvišeni Allah zaklinje, onda se koristi قسم (Al-Šāy` 1993: 238-241).

\section{Sinonimi طريق i سبيل}

Riječ سبيل se odnosi na put u onim situacijama u kojima se očekuje olakšanje ili ima doza jasnosti, tj. koristi se u kontekstu dobra (Kur'an: طريق طَّisti u kontekstu kuđenja ili prijetnje

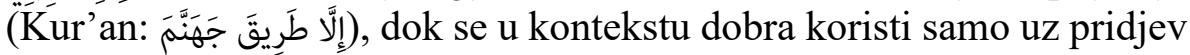
ili dodatak koja od njega odstranjuju negativnu konotaciju (طريق مستقيم). Zanimljivo je da je u Kur'anu riječ سبيل korištena 174 puta, dok je izraz طريق korišten samo 11 puta (Al-Šày“ 1993: 263-266). 


\section{Sinonimi إيجاز i اختصار}

Termin اختصار se odnosi na skraćivanje onoga što je već rečeno ili napisano, dok je إيجاز skraćivanje onoga što nastaje, tj. reduciranje onoga što se želi reći ili napisati (Al-Ḥusaynī 2012: 27).

\section{S بعل i زوج}

Termin زوج se koristi za osobu koja je sklopila bračni ugovor, bez obzira da li je konzumirala brak ili ne, dok se termin بعل koristi isključivo za osobu koja je konzumirala brak (Al-Ḥusaynī 2012: 104).

\section{Sinonimi لعب i لهو}

Termin لعب se odnosi na svaku vrstu igre, bilo ona korisna i edukativna ili ne, poput sportskih igara, šaha i slično, dok termin $ه ـ$ podrazumijeva svaku beskorisnu igru koja zaokuplja čovjeka i odvraća ga od korisnih stvari (Al-'Askariyy 1997: 254).

\section{Sinonimi جسم i جسد}

Riječ جسد odnosi na tijelo čovjeka i ostalih bića (Al-Nağafiyy 2016: 64).

\section{Sinonimi صوم i صيام}

Riječ صيام označava sustezanje od hrane, pića i spolnog odnosa uz postojanje namjere, dok riječ صوم podrazumijeva općenito sustezanje, bilo da se radi o prethodno navedenom ili govoru, kao što o tome Kur'an

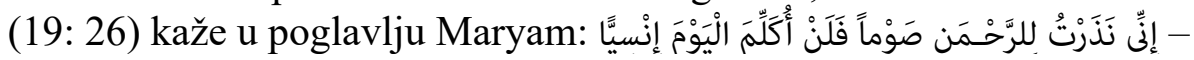
"Ja sam se zavjetovala Milostivom da ću šutjeti, i danas ni s kim neću govoriti”' (Al-Nağafiyy 2016: 82).

\section{Sور i ظلم}

Termin جور se odnosi isključivo na nepravdu od strane vladara (kako

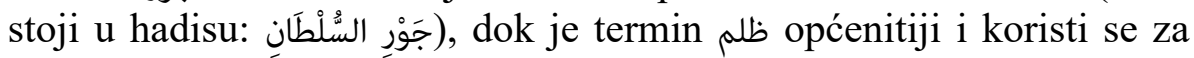
svaki vid nepravde, bilo da se radi o vladaru ili nekom drugom (Al'Askariyy 1997: 231). 


\section{Sinonimi إجازة i إذن}

Termin إذن se odnosi na dozvolu za nešto što će se desiti nakon dozvole, dok se termin إجازة odnosi na radnju koja se već desila i koja iziskuje odobravanje osobe koja to odobravanje može dati, pa se tako termin koristi za odobravanje nasljednika za oporuku iznad trećine koju oporuči osoba koja se nasljeđuje (Al-Husaynī 2012: 33).

\section{Sinonimi تلاوة i ق تراءة}

Riječ قراءة ima široko značenje i označava svako čitanje, dok riječ označava ono čitanje/učenje koje se čini s dozom poštovanja i pijeteta, a odnosi se najčešće na Časni Kur'an. Također, riječ تلاوة etimološki u sebi sadrži slijed/slijeđenje, tako da se odnosi na ono čitanje gdje ima dosta riječi i gdje se prilikom čitanja čitaju riječi jedna za drugom, tj. slijede jedna drugu, ili gdje se pročitano nakon čitanja/učenja treba slijediti i čija uputstva treba uvažavati i primjenjivati, kao što je to slučaj sa Časnim Kur'anom (Al-Šāy‘ 1993: 279-280).

\section{Sinonimi إكمال i i إتمام}

U svakodnevnom životu se značenje ove dvije riječi poistovjećuje. Međutim, imenica إقام se odnosi na dopunjavanje kojim bi neko (ili nešto) bi(l)o potpun(o), dok se إكمال koristi u kontekstu otklanjanja nedostataka koja su naknadno okrnjila nešto što je bilo potpuno (AlŠāy‘ 1993: 260). Kur'anski ajet u kojem se spominju ova dva sinonima dovoljno ukazuje na postojanje razlike između njihovih značenja, a on

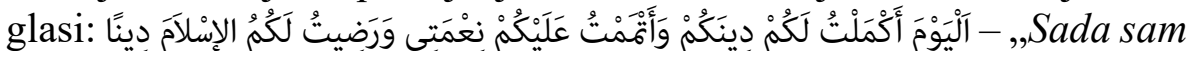
vam vjeru vašu usavršio i blagodat Svoju prema vama upotpunio $i$ zadovoljan sam da vam islam bude vjera" (Kur'an 5: 3).

\section{Sinonimi قرض أ دَين}

Riječ دَرض se odnosi na dūg koji ima rok za njegovo vraćanje, dok je dūg koji nema rok za vraćanje (Al-Nağafiyy 2016: 82). 


\section{Imenice ذرية}

Riječ آ označava čovjekovu rodbinu, dok ذرية označava njegovo potomstvo, iako mnogi često poistovjećuju njihova značenja i smatraju sinonimima, tako da riječ آ ima općenitije značenje nego riječ ذرية. Najčešće se riječ آ koristi samo za ugledne porodice (Al-'Askariyy 2012: 7).

\section{Sinonimi قلس i قa}

Glagol قعد se koristi isključivo za sjedenje koje slijedi nakon ustajanja, dok se glagol جلس

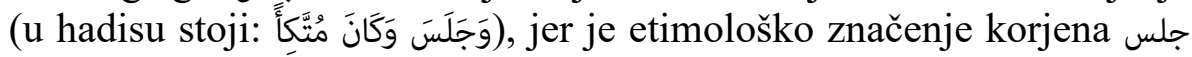
قعد قعد قعد قعد suprotno, tj. spuštanje, tako da se nakon stojanja koristi glagol umjesto جلس (Ibn-Fāris 1979: 1/473).

Također, druga razlika između korijena قعد i جعد i jeste u periodu trajanja sjedenja, pa ako je duže onda se koristi قعد, a ako je kraće onda se koristi جلس. Na tragu toga, za žene koje većinu vremena provode u kućama i često ne izlaze izvan njih se kaže da su قوالْقَوَاعِدُ : جوالس (Kur'an (مِنَ النَّّاِْ (Al-Šāy‘ 1993: 288).

\section{Sinonimi}

Izraz تجسس se odnosi na istraživanje tajnovitih i skrivenih stvari, općenito tuđih mahana, a od toga dolazi i imenica جاسوس قahoda“ i u većini slučajeva se odnosi na nešto što je negativno, dok se تحسس odnosi na traganje za tajnama i općenito osluškivanje tuđeg govora, ali tragajući i nadajući se pozitivnim vijestima (Al-Nağafiyy 2016: 50).

\section{Sinonimi حياء i خجل}

Izraz خجل se odnosi na sramežljivost, odnosno na psihičko stanje nemoći koje se manifestuje kroz ponašanje, dok je حياء stid ili odustajanje od nečega u stanju moći zbog moralnih principa, tako da je خ خ ustručavanje od činjenja korisnih stvari, dok je حياء odustajanje od djela koja, po subjektivnoj procjeni osobe, nisu pohvalna (Al-'Askariyy 2012: 212). 


\section{Sinonimi كفل i نصيب}

Iako se oba termina spominju u Kur'anu kao sinonimi za udio, postoji razlika između njihovih značenja. Termin نصيب označava neograničeni udio u nečemu u kontekstu dobra, dok termin كفل označava ograničeni udio u kontekstu nečega što je negativno. Primjer za to jeste kur'anski

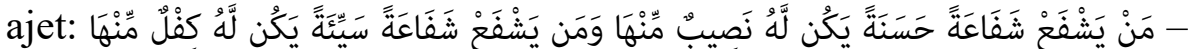

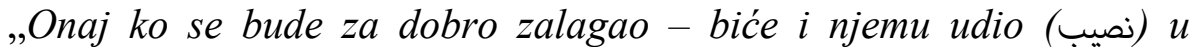
nagradi, a onaj ko se bude za zlo zauzimao - biće i njemu udio (كفل) u kazni“، (Kur'an 4: 85). Termin نصيب ukazuje na neograničeni udio (nagradu), dok كفل ukazuje na ograničeni udio (kaznu), jer se za loša djela ne kažnjava osim koliko je onaj koji ga čini zaslužio, jer Uzvišeni kaže: وَمَنَ - Ko čini zlo, biće prema njemu kažnjen " (Kur'an 40: 40).

\section{Sinonimi جل i خلق}

Glagol خلق sَứ odnosi na stvaranje nepostojećeg iz nečega što već postoji, kao što stoji u Kur'anu: وَبَدَاً خَلْقَ الْإِنْسَانِ مِنْ طِين , Koji je prvog čovjeka stvorio od ilovače“" (Kur'an 32: 7), dok se glagol odnosi na potčinjavanje nečega nečemu ili da mu bude na usluzi, kao što to Kur'an

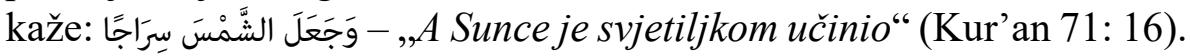

\section{Sinonimi خوان iائدة}

Imenica مائدة se koristi za sto na kojem se nalazi hrana, u protivnom se za njega kaže خِوان, kao što se za bocu u kojoj se nalazi piće kaže كأس dok se za onu u kojoj se ne nalazi piće, kaže زجاجة (Al-Ta'ālibiyy 2000: 59).

\section{Sinonimi استخهام iوأ سوال}

Iako imenice استفهام iqؤال koristimo kao sinonime za pitanje, ipak između njih postoji razlika, jer riječ استفهام označava ,,pitanje za nešto što se ne zna ili u nešto u što se sumnja“, dok سؤال može da označava „pitanje za nešto što se zna ili za nešto što se ne zna“. 


\section{Zaključak}

Izučavanje ove jezičke discipline je od velikog značaja za očuvanje leksičkog blaga arapskog jezika, ali i zbog ispravnijeg i preciznijeg shvatanja Objave koja se manifestuje kroz Kur'an i izreke Muhammeda, s.a.v.s.

Nakon prezentiranja stavova zagovornika i negatora postojanja sinonimije, može se zaključiti da je razlika između njih terminološke, a ne suštinske prirode, jer se oni slažu da postoje razlike između pojedinih sinonima, ali da je nemoguće ustvrditi razliku između pojedinih sinonima, što nam ukazuje na postojanje apsolutne (tzv. istoznačnica) i djelimične sinonimije (bliskoznačnica), gdje bi prva ukazivala na sinonime između kojih postoji istoznačnost, dok kod drugih postoje određene razlike u nijansama i zbog toga se one i zovu bliskoznačnice. Prema tome, jezičku disciplinu al-furūq al-lugiawiyya možemo podvesti pod djelimičnu sinonimiju.

Značajan broj djela je napisan na temu semantičkih razlika između sinonima. Motivi kojim su se rukovodili autori kada su pisali djela iz ove discipline su različiti, ali su najznačajniji očuvanje arapskog jezika i njegovo širenje među budućim naraštajima. Jedan od njih je i da se u njihovim djelima sačuvaju od zaborava originalni izrazi koji su na veoma jasan i precizan način ukazivali na pojedina specifična značenje i pojmove.

Sitne ali bitne razlike između sinonima su posebno interesantne $u$ kontekstu razumijevanja kur'anskog teksta, gdje je kontinuirano ponavljanje pojedinih sinonima $\mathrm{u}$ određenim situacijama usmjerilo razmišljanja komentatora Kur'ana i ponukalo ih da crpe dodatne poruke iz Časnog Kur'ana, koje bez njihovog poznavanja nisu mogli dokučiti.

$\mathrm{Na}$ našem jeziku, koliko je nama poznato, nije bilo ovakvih radova i smatramo ovaj rad pionirskim doprinosom daljem istraživanju ove jezičke discipline, posebno na planu praktičnih primjera semantičkih razliku između kur'anskih sinonima.

\section{Literatura}

1. 'Askariyy (al-), 'Abū Hilāl (أبو هلال العسكري), (1997) Al-Furūq allug̉awiyya (الفروق اللغوية), Dār al-'ilm wa al-țaqāfa, Al-Qāhira. 
2. 'Askariyy (al-), 'Abū Hilāl, wa Husaynī (al-), Nūr al-dīn bin Ni'matullāh (أبو هلال العسكري ونور الدين بن نعمة الله الحسيني) (2012) Muğam alfurūq al-luğawiyya al-ḥāwì li kitāb 'Abī Hilāl al-Askariyy wa ğuz' min

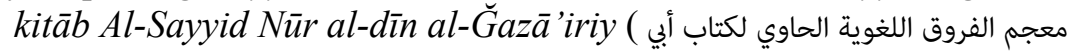
(هلال العسكري وجزء من كتاب السيد نور الدين الجزائري (), Mu'assasa al-našr al-'islāmiy, Al-Qumm.

3. 'Anīs, 'Ibrāhīm (إبراهيم أنيس) (1992) t: 8 Fī al-lahağāt al- 'arabiyya (إني (اللهجات العربية), Al-Maktaba al-'Anğlū al-Miṣriyya, Al-Qāhira.

4. Dūrī (al-), Muhammad Yās Huụar (محمد ياس خضر الدوري) (2005) Daqā'iq

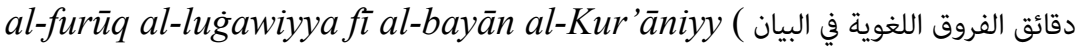
(القرآني Dār al-kutub al-'ilmiyya, Bayrūt.

5. Ğāḥiz (al-), 'Abū 'Utmān 'Amr 'ibn Baḥr (أبو عثمان عمرو بن بحر الجاحظ) (1998) Al-Bayān wa al-tabyīn (البيان والتبيين), Maktaba al-Hुānğ̄î, AlQāhira.

6. Husaynī (al-), Nūr al-dīn bin Ni'matullāh (نور الدين بن نعمة الله الحسيني)

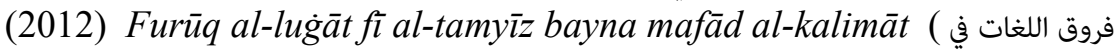
(التمييز بين مفاد الكلمات), Al-Našr al-’islāmiyy, Al-Qumm.

7. Korkut, Besim (prevod) (1992) Časni Kur'an, Maṭba al-Kur'ān alkarīm, Al-Madīna al-Munawwara.

8. Kulayb Mūsā, Yasamīn Sa'd (ياسمين سعد كليب موسى) (2006) Kutub al-furūq al-luǵawiyya fì ḍw' 'ilm al-dilāla (كتب الفروق اللغوية في ضوء علم الدلالة), risāla al-doktorāh, Al-Ğāmi'a al-’Urduniyya.

9. Mihić, Tina (2012),,Sinonimi i razlike u hrvatskim prevodima na primjeru Lk 22,54-62“, Lahor, Zagreb.

10. Muftić, Teufik (1998) Gramatika arapskog jezika, Ljiljan, Sarajevo.

11. Nağafiyy (al-), 'Ali ’Akbar ibn Maḥmūd (علي أكبر بن محمود النجفي) (2016) Al-Furūq al-luǵawiyya (الفروق اللغوية), Al-Maktaba al-'Azhariyya li alturāt, Al-Qāhira.

12. Șāliḥ (al-), Șubḥ̄ (صبحي الصالح) Dirāsāt fi fiqh al-lug̉a (2009) (راسات في فقه اللغة), Dār al-'ilm lil-malāyīn, Bayrūt.

13. Šāy' (al-), Muhammad ibn 'Abd al-Raḥmān ibn Ṣālih ( محمد بن عبد الرحمن (1993) Al-Furūq al-luǵawiyya wa 'ataruhā fì tafsīr alKur'ān al-Karīm (الفروق اللغوية وآثارها في تفسير القرآن الكريم), Maktaba al'Ubaykān, Al-Riyaḍ.

14. Ta'ālibiyy (al-), 'Abū Manșūr (أبو منصور الثالبي) (2000) Fiqh al-lug $a$ wa ’asrār al- 'arabiyya (فقه اللغة وأسرار العربية), Al-Maktaba al-'aṣriyya, Bayrūt. 
15. Tafra, Branka (2018) "Razgraničavanje istoznačnosti i bliskoznačnosti”, Od fonologije do leksikologije: Zbornik u čast Mariji Turk, Sveučilište u Rijeci, str. 215-230. 
dr. sci. Hajrudin Hodžić, ext. prof.

University of Bihać

Islamic Pedagogical Faculty

Email: hajrudinhodri@gmail.com

\section{SEMANTIC DIFFERENCES BETWEEN SYNONYMS AS AN EXAMPLE OF THE RICHNESS OF THE ARABIC LANGUAGE}

\section{Abstract}

Semantic differences between synonyms (ar. Al-furüq al-lugawiyya - اللغوية الفروق (is a scientific discipline in Arabic that explores the differences between individual words that, at first glance, have identical meanings. The importance of studying this topic is reflected in the most precise interpretation and understanding of sacred texts (Qur'an and the words of Muhammad, s.a.v.s.), then the preservation of rich A rabic vocabulary, as well as tearing from oblivion expressions that have more precise meanings. In the first period of the development of Arabic lexicography, the authors who wrote works from this scientific discipline thus made a great contribution to its enrichment, and one of the most famous works is Al-Furūq al-lug awiyya (اللغوية الفروق) ('Abü Hiläl al'Askariyya (395/1005).

Keywords: Arabic language, semantic differences between synonyms (al-furūq alluǵawiyya (richness of Arabic language, synonymy, Qur'anic commentary 


$$
\begin{aligned}
& \text { الدكتور المشارك خيرالدين هوجيتش } \\
& \text { جامعة بيهاتش الشت المشاك } \\
& \text { كلية التربية الإسلامية بئن }
\end{aligned}
$$

E-mail: hajrudinhodzic@gmail.com

\section{الفروق اللغوية بين المرادفات كمثال على ثراء اللغة العربية}

\section{الخلاصة}

الفروق اللغوية بين المرادفات تخصص علمي في اللغة العربية يستكشف الفروق بين الفين الفراني الكلمات الفردية التي لها للوهلة الأولى معاني متطابقة.

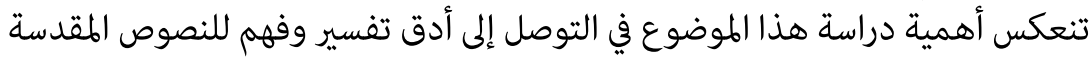

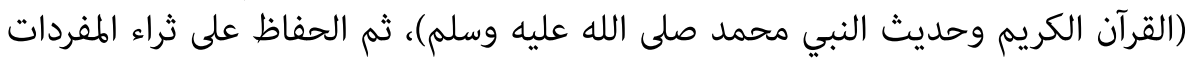

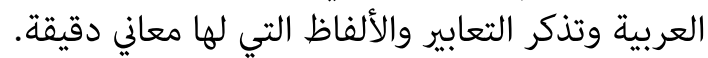

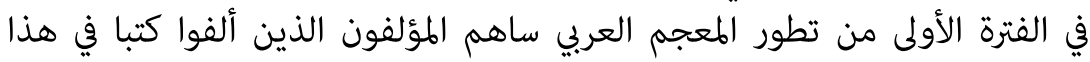

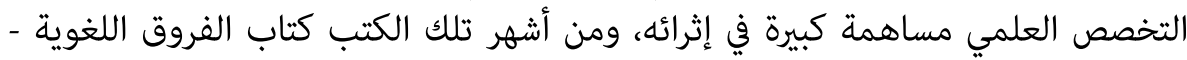
لأبي هلال العسكري(395/1005) .

الكلمات المفتاحية: اللغة العربية، الفروق اللغوية بين المرادفات، ثراء اللغة العربية،

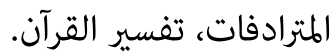

